\section{A granite cliff deep in the North Atlantic}

WE report here preliminary results from the detailed sampling of granitic basement at a depth of $4,000 \mathrm{~m}$ at the lower edge of the Armorican continental margin near $48^{\circ} \mathrm{N}$ and $12^{\circ} \mathrm{W}$. We consider that we have sampled here the extreme lateral limit of the continental crust where local exposures emerge from under a cover of Cainozoic, Mesozoic and probable Palaeozoic sediments.

The Goban Spur', part of the deep continental margin off France and the UK, lies between the Celtic shelf and the Porcupine abyssal plain $\sim 550-\mathrm{km}$ West of Brest and Land's End (Fig. 1). A seismic profile of the continental slope in this area shows a succession of three main 'gradins' (steps) with intermediate sedimentary basins (Fig. 2). The westernmost and deepest of the steps has a steep southwestern slope Granite Cliff 4,000 near the 4,000-m isobath. Twenty $\mathrm{km}$ further to the south-west is the marginal hill or high named by us Menez Bihan. At each of the three steps the substratum appears as an outcrop, passing under the sedimentary cover of the adjacent basin. The substratum seems to be continuous between the steps; it is 3-s d.t.t. (double travel time) deep to the east of the first step and 8-s d.t.t. deep at the foot of the continental slope (Fig. 2).

In December 1975, with the RV Le Suroït, we dredged fragments of granite from the steep slope we now call Granite Cliff 4,000 (Fig. 2). On the side of King Arthur
Canyon, at a depth of $3,000 \mathrm{~m}$, we dredged a pebble containing fossil material identified as Devonian. To investigate further these findings, and to make sure that the granite dredged was not erratic, we went back to the area in February 1976 with the RV Jean Charcot.

We made a bathymetric survey to clarify the relationship between Granite Cliff 4,000 and Menez Bihan and then moored three acoustic beacons on the bottom: two at the foot of the cliff and one near the top (all within the circle in Fig. 1). The distance between beacons was $\sim 6,000 \mathrm{~m}$. On board, on a plotting table, the track of the ship and the track of the dredge (or camera) on the bottom were then followed in real time with a precision of $\sim 30 \mathrm{~m}$. In this manner it is possible to visualise the work of the dredge on the bottom and, in combination with the tensiometer, to determine with precision the position of breaking $-\mathrm{fff}$ of the rocks. For the seafloor photography, we used both a troika (a toboggan that slides on the bottom) and a camera frame attached to the cable just ahead of the dredge.

The dip of the slope of Granite Cliff 4,000 reaches at least $30^{\circ}$ (the maximum slope which can be detected with the conventional $12-\mathrm{kHz}$ precision depth recorder we used). The base of the slope is very straight in the studied area and this linearity, coupled with the apparent steepness of the slope, suggests that it is a fault escarpment. The foot of the slope is $4,150-\mathrm{m}$ deep and the top lies at $3,150 \mathrm{~m}$. Photographs of the slope show sediments on the lower and

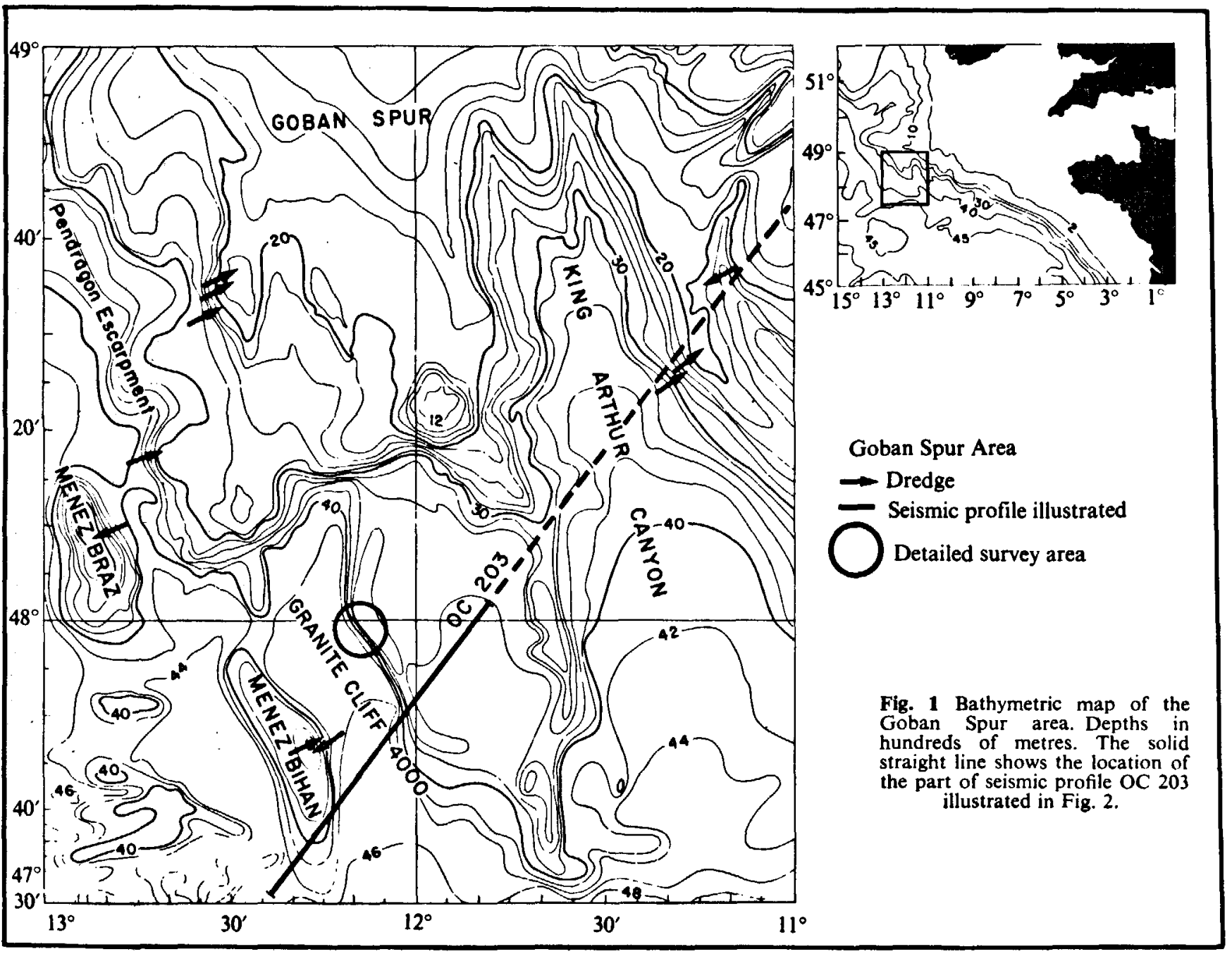



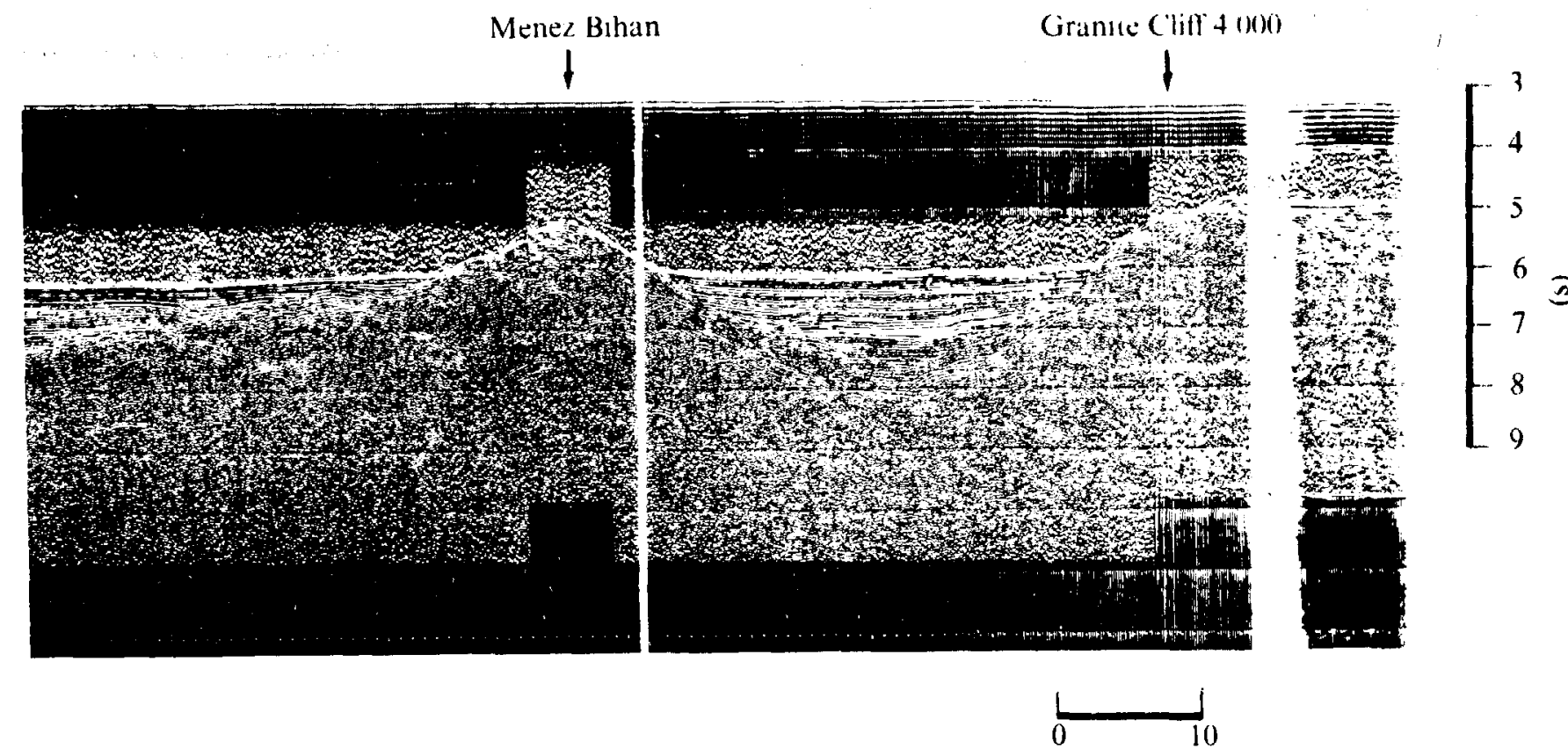

$(\mathrm{km})$

Fig. 2 Seismic profile OC 203 made by the RV Florence. Location of the profile is shown on Fig. 1. Vertical exaggeration is . 5.

upper parts. In between, the sediment cover is thin and there are round outcrops, some of which show fractures.

Four dredgings with the acoustic navigational control were made and in each dredge we found blocks of granitic rock. Their appearance and the dredge-wire tensiometer records indicate that some of the blocks were torn off outcrops, and support the evidence from the seafloor photographs that we are not dealing with ice-rafted erratics, except perhaps for a few associated pieces of dark or light granulite. the autochonous origin of which is still in doubt. In addition. the presence of all the rocks found can be reasonably associated with the setting in which they occur.

The granitic blocks are more or less weathered and are partially covered with ferromanganese crusts up to $12-\mathrm{cm}$ thick. They are granodiorites, tending to quartz diorites. The minerals present are quartz with undulating extinction. biotite (abundant), andesine (abundant, automorphic and zoned), potassic feldspar (rather scarce), apatite, zircon and opaque minerals (J. Didier, personal communication). The fabric is clearly directional, and the biotites are slightly curved.

Similar rocks possibly a little more altered. were dredged on the flanks of Menez Bihan (Fig. 2). The apparent continuity between Menez Bihan and Granite Cliff 4.000 (Fig. 2) is thus demonstrated. On geomorphic grounds (Fig. 1) it seems probable to us that Menez Braz to the north-west is also granitic. but we obtained no samples because of the considerable thickness of sediment there.

In three areas we dredged fragments of old sedimentary cover lying above the granitic substratum. From the flanks of Menez Bihan we collected a fragment of quartzitic sandstone. The remainder of the dredge-haul was entirely granitic Granite Cliff 4.000 yielded numerous samples of limestones some of them of possible Mesozoic age. On the Pendragon escarpment (Fig. 2), at a depth of between 3.000 and $2.000 \mathrm{~m}$. the dredge recovered no granite, but a few metamorphic rocks and a rich sample of old sedimentary rocks: fine green sandstones, marly chalk with veins of calcite, grey claystone, sedimentary breccias and quartzite. No fauna has been found on preliminary examination, but we speculate that the rocks represent Palaeozoic or even older sediments.
The dredging of 'in place' granitic rocks at $4.000 \mathrm{~m}$ is exceptional and has important implications. In geometric reconstructions of the early opening of the North Atlantic, for example, many authors ${ }^{2}$ have used a shallower depth $(1.000$ to $2.000 \mathrm{~m})$ and hence a more easterly limit. for the edge of the continental crust. The maximum depth of the granite is evidently even greater than $4.000 \mathrm{~m}$. Judging from the seismic profile (Fig. 2), the probable continuity of the granitic substratum between Granite Cliff 4.000 and Menez Bihan lies at a depth of $8 \mathrm{~s}$ d.t.t. (between 6,500 and $7,500 \mathrm{~m}$ ).

To the south-west of Menez Bihan lies a low hill above the $4.000-\mathrm{m}$ water depth (Fig. 1). Seismic profiles show that the basement of this hill is rough: quite different in character from that of Menez. Bihan. Magnetic records show that the east flank of the low hill marks the beginning of a sharp anomaly $\left(500 \times 10^{-9} \mathrm{~T}\right)$ whereas the magnetic profile on the continental side of the hill is relatively flat. According to $\mathrm{C}$. Williams (personal communication), anomaly $34(\sim 85 \mathrm{Myr})$ passes close by. The hill does not seem to have the acoustic character of an intrusion, and may indeed mark the contact between oceanic crust and continental crust ${ }^{3}$.

The granodioritic character of the granitic massifs we sampled suggests that they are orogenic granites, presumably of the intrusive type and of deep origin. It is difficult to envisage their emplacement during early rifting (90-100 Myrı. None of the granites is alkaline and they are neither porphyritic nor strongly deformed. On the other hand, they may well be late generation (post-phase 2) granodiorites of Hercynian age (J. Didier, personal communication). They may represent intrusions in a granulitic basement which would explain the rocks belonging to the granulitic facies that we dredged from Granite Cliff 4,000 and from Menez Bihan. The basement underlying the continental slope itself is probably not made up of granodiorites. The latter usually appear as intrusions in the Hercynian chains (for example, the Armorican massif).

The oldest sedimentary rocks are epimetamorphic with at least two phases of deformation (folding). They resemble the Palaeozoic and Upper Precambrian (Brioverian) rocks of the Armorican massif (M. Gravelle, personal communication). We interpret this evidence as further support for 
arguing that the basement underlying the continental margin east of Menez Bihan is probably the older Hercyninan basement (granulite with granodiorite intrusions).

The direction of Granite Cliff 4,000 is similar to the Pendragon Escarpment $\left(\mathrm{N} 30^{\circ} \mathrm{W}\right)$ and may be related to Hercynian faults ${ }^{4}$. During the rifting phase of the North Atlantic normal faulting associated with the subsidence of the continental blocks probably reactivated these old features. During the initial uplift phase, Menez Bihan would-in most models-have been on top of the uplifted crust and would consequently have been deeply eroded. Thus it seems reasonable that we dredged granite and Mesozoic limestone on Granite Cliff 4,000 and no Palaeozoic sediments. The upper pant of Pendragon Escarpment, further away, was not, however, eroded to such an extent. Subsequently, thermal processes led to inversion of relief, with normal faulting along the Horcynian zone of weakness and subsidence of the continental margin.

David Needham and Xavier Le Pichon gave us useful advice in their reviews of the manuscript. Jean Didier,
Michel Gravelle, Claude Babin and Annick Pelhate made preliminary descriptions of the samples.

\section{Guy Pautot}

Vincent Renard

GERARD AUFFrET Leo Pastouret

Centre Océanologique de Bretagne,

B.P. 337, 29273, Brest Cedex,

France

Institut Français du Pétrole,

Olivier de Charpal

1 à 4, avenue de Bois-Préau,

92500 Rueil-Malmaison,

\section{France}

Received June 22; accepted August 23, 1976. 1 Laughton, A. S., Roberts, D. G., and Graves, R., Sheet 3, No. C 6568 (Institute Bullard. E. C., Everett, J. E., and Smith A. G., Phil. Trans.

3 Pitman, W.C.. III, Larson, R. L., and Herron, E. M. Roberts, D. G., Geology of Continental Margins (edit. by Burk. C. A., and Drake. C. L.), (Springer-Verlag, New York, 1974). 